\title{
Nilai Gizi serta Daya Terima Biskuit dengan Penambahan Tepung Ikan Layang (Decapterus russelli) dan Ikan Selar (Caranx SP) \\ (The Nutritional Value and Acceptability of Biscuits with the Fish Addition of Indian Scad (Decapterus russelli) and Trevally (Caranx. sp) Fishmeal)
}

\author{
Eddy Setyo Mudjajanto ${ }^{1}$, Wiwin Kholilah ${ }^{2}$ dan Nurillah Amaliah ${ }^{2}$ \\ ${ }^{1}$ Staf Pengajar Manajemen Industri Jasa Makanan dan Gizi, Diploma IPB \\ ${ }^{2}$ Lulusan Jurusan Gizi Masyarakat IPB
}

Diterima/disetujui : 18 Juni 2015/ 27 Juni 2015

\begin{abstract}
S
The general purpose of this research was to study the nutritional value and acceptability of biscuits with the addition of Indian Scad (Decapterus russelli) and Trevally (Caranx sp) fishmeal. This study was divided into two stages: a preliminary study and further research. Generally, Indian Scad fishmeal has $11.65 \%$ moisture content, 7.94\% ash, $89.26 \%$ protein, 0.34\% fat and 36.66 ppm iron, and the yield is $15.96 \%$. However, the Trevally has $7.34 \%$ moisture content, $0.53 \%$ fat, $89.86 \%$ protein, $10.92 \%$ ash, $18.05 \%$ iron, and the yield is $12.65 \%$. Based on the state of fat, ash, iron and yield, the chosen fish to be further tested was the Indian Scad. Nutrient content of controlled and selected biscuits ranged from 2.33\%-3.93\% water content, $1.61 \%-2.82 \%$ ash, $6.60 \%-20.01 \%$ protein, $18.61 \%-21.90 \%$ fat, $58.51 \%-70.01 \%$ carbohydrates, 928.28-933.92 ppm iron, and 0.00-3.14 mg O2/100 g peroxide. The content of the biscuit met the ISO standard No. 01-2973-92 except for the levels of fat and carbohydrates which were less than the standard. Nutrient loss of controlled and selected biscuits during the processing were of $72.3 \%$ and $83.45 \%$ water content, $0.61 \%$ and $0.36 \%$ ash, $4.65 \%$ and $1.33 \%$ protein, $0.09 \%$ and $0.59 \%$ fat, $0.46 \%$ and $0.47 \%$ iron. The results showed that the addition of Indian Scad fishmeal was significantly affected on the moisture, ash, protein, fat, carbohydrates and peroxide, but had no effect on iron levels.
\end{abstract}

Keyword : fishmeal, nutritional value, indianscad, trevally

\section{PENDAHULUAN}

Dari empat masalah gizi kurang di Indonesia, anemia gizi besi merupakan masalah yang relatif masih tinggi dan penanganannya belum menunjukkan hasil yang menggembirakan. Menurut Dwiriani (1997) anemia gizi besi umumnya disebabkan oleh rendahnya pangan sumber zat besi yang dikonsumsi, rendahnya ketersediaan biologis dari pangan yang dikonsumsi, gangguan penyerapan atau karena kehilangan darah. Adapun upaya yang dapat dilakukan untuk mengatasi masalah anemia gizi pada berbagai kelompok umur termasuk ibu hamil antara lain dengan fortifikasi zat besi dan penambahan bahan pangan sumber zat besi. Fortifikasi tepung terigu dan roti dengan dengan zat besi menunjukkan adanya perubahan citarasa makanan yaitu tepung menjadi kecoklatan dan roti tercium bau karat dari oksidasi zat besi. Oleh karena itu, zat besi yang ditambahkan sebaiknya dalam bentuk yang sudah dienkapsulasi agar lebih tahan terhadap proses oksidasi (Komari 1995).

Ikan merupakan bahan pangan yang kaya akan zat besi selain itu juga cukup murah, sehat dan bergizi dibandingkan bahan pangan lainnya. Sekitar $50 \%$ zat besi dalam ikan 
berbentuk hem dimana hem tersebut mudah diabsorbsi yaitu sekitar 15-35\% dan juga adanya asam amino sistein, valin dan histidin pada ikan yang merupakan zat aktif pemacu penyerapan zat besi (Soekirman 2000).

Beberapa jenis ikan yang potensial dikembangkan menjadi tepung ikan diantaranya adalah ikan layang (Decapterus russelli) dan ikan selar (Caranx sp). Pada tahun 2003 produksi ikan laying Indonesia mencapai 368221 ton atau 6.45\% dari total produksi perikanan tangkap di laut. Sedangkan produksi ikan selar tahun 2013 mencapai 188059 ton atau $3.29 \%$.

Bahan makanan yang dapat digunakan untuk pemanfaatan atau pengaplakasian tepung ikan misalnya adalah roti, biskuit dan crackers (Dwiyitno 1995). Biskuit dipilih sebagai alternatif produk yang difortifikasi dengan zat besi dan tepung ikan karena biskuit merupakan salah satu bentuk makanan yang disukai oleh anak-anak maupun orang dewasa dan memiliki daya simpan yang panjang (Manley 1983).

Penelitian ini bertujuan untuk mempelajari nilai gizi serta daya terima biskuit dengan penambahan tepung ikan layang (Decapterus ruselli) dan ikan selar (Caranx SP)

\section{METODOLOGI}

\section{Tempat Penelitian}

Penelitian ini dilaksanakan di Laboratorium Pengolahan Pangan dan Laboratorium Kimia Gizi, Faperta-IPB, Laboratorium Terpadu IPB dan Pilot Plant Pusat Studi Pangan dan Gizi (PSPG), LP-IPB serta di Pusat Penelitian dan Pengembangan (Puslitbang) Perikanan dan Eksplorasi Hasil Laut, Slipi, Jakarta.

\section{Bahan dan Alat}

Bahan-bahan yang digunakan dalam penelitian terdiri dari ikan layang dan selar, tepung terigu, tepung beras, margarin, telur, gula halus, baking powder, susu skim, vanili, coklat bubuk dan jeruk nipis serta bahan-bahan kimia untuk analisis. Peralatan yang digunakan meliputi peralatan untuk pembuatan tepung ikan (alat pengukus, screw press, mechanical dryer, penggilingan) alat-alat untuk membuat biskuit, serta peralatan untuk analisis kimia seperti oven, tanur, soxhlet, labu kjeldahl, Atomic Absorbtion Spectrofotometer (AAS).

\section{Metode Penelitian}

Penelitian dilakukan dengan dua tahap yaitu penelitian pendahuluan dan penelitian lanjutan. Pada penelitian pendahuluan ini dilakukan pembuatan tepung ikan layang dan selar.. Analisis komposisi tepung ikan layang dan selar kemudian berdasarkan komposisinya ditentukan tepung ikan yang dipilih. Pembuatan biskuit tepung ikan terpilih dan difortifikasi dengan zat besi. Uji organoleptik dilakukan untuk mengetahui formula biskuit yang paling banyak diterima oleh panelis. Penelitian lanjutan, setelah diperoleh biskuit terpilih maka biskuit tersebut dengan kontrol (tanpa penambahan tepung ikan dan tanpa rasa) disimpan dengan menggunakan pengemas polipropilen. Penyimpanan dilakukan selama satu bulan dengan titik-titik pengamatan 0,2 dan 4 
minggu. Pada setiap titik pengamatan biskuit kontrol dan biskuit terpilih diuji organoleptik dan dianalisis komposisi kimianya (kadar air/metode oven, abu/metode pengabuan kering, protein/metode kjeldahl, lemak / metode soxhlet, karbohidrat/metode by different, zat besi/metode AAS dan bilangan peroksida). Selain itu juga dilakukan analisis komposisi kimia adonan sebelum dipanggang dan setelah dipanggang untuk mengetahui kehilangan zat gizi selama proses.

\section{Rancangan Percobaan dan Analisis Data}

Rancangan percobaan menggunakan Rancangan Acak Lengkap (RAL) faktorial yang terdiri dari dua ulangan dan dua faktor yaitu faktor penambahan tepung (A) dan faktor lamanya penyimpanan ( 0,2 dan 4 minggu). Untuk mengetahui pengaruh perlakuan terhadap kandungan zat gizi biskuit dan terhadap tingkat kesukaan biskuit selama penyimpanan dianalisis dengan analisis sidik ragam (ANOVA) dan jika hasil analisis menunjukkan perbedaan yang nyata maka dilakukan uji lanjut dengan menggunakan uji wilayah berganda Duncan (Walpole 1995). Sedangkan untuk mengetahui daya terima ibu hamil terhadap biskuit dilakukan uji hedonik. Uji hedonik dilakukan terhadap warna, aroma, rasa, kerenyahan dan penerimaan umum dengan skala : 1 (sangat tidak suka), 2 (tidak suka), 3 (biasa), 4 (suka) dan 5 (sangat suka). Data hasil uji hedonik dianalisis secara deskriptif berdasarkan persentase penerimaan panelis dan skor modus dari masing-masing taraf perlakuan. Data hasil uji hedonik biskuit tujuh formula dan biskuit rasa dianalisis dengan uji statistik non parametrik Friedman dan jika berbeda nyata dilanjutkan dengan uji Multiple Comparison Test (Damayanthi et al. 1997).

\section{HASIL DAN PEMBAHASAN}

\section{Penelitian Pendahuluan}

\section{Pembuatan Tepung Ikan Layang dan Ikan Selar}

Bahan dasar yang digunakan dalam pembuatan tepung ikan terdiri dari ikan layang dan ikan selar tanpa kepala, ekor dan isi perut. Ikan dibersihkan dan dicuci dengan air dingin sebanyak 2-3 kali. Ikan kemudian dikukus selama 30 menit dan dipres dengan screw press. Pada tahap selanjutnya ikan dikeringkan dengan mechanical dryer, digiling dan disaring dengan saringan ukuran 60 mesh.

Pada pembuatan tepung ikan dilakukan ekstraksi lemak sebanyak dua kali. Tujuan ekstraksi untuk mengurangi kandungan minyak dan sekaligus meminimalkan flavor (bau) ikan. Selain itu juga untuk mencegah proses ketengikan selama penyimpanan (Moeljanto 1982). Ekstraksi lemak tepung ikan dilakukan dengan pelarut heksana dan dilakukan dengan cara pengocokan.

\section{Kandungan Zat Gizi Tepung Ikan Layang dan Ikan Selar}

Ekstraksi lemak yang dilakukan terbagi atas dua tahap. Tahap pertama ekstraksi dilakukan selama lima jam. Ekstraksi ini mampu menurunkan kandungan lemak ikan layang dari $9.11 \%$ bb menjadi $0.88 \%$ bb (menurunkan $90.30 \%$ ). Tahap kedua ekstraksi dilakukan selama satu jam dan menghasilkan tepung $0.29 \%$ bb atau $0.34 \%$ bk. Sedangkan 
untuk ikan selar turun dari $5.40 \%$ bk menjadi $0.53 \%$ bk. Jika dibandingkan kedua tepung ikan tersebut maka pilihan jatuh ke tepung ikan layang dengan beberapa pertimbangan diantaranya kadar abu dan kadar lemak ikan selar lebih besar dan rendemen serta kadar zat besi lebih rendah dibanding ikan layang. Selain daripada itu produksi ikan layang lebih banyak dibanding ikan selar dan juga harganya lebih murah ikan layang. Untuk selanjutnya yang akan diujicobakan hanya tepung ikan layang. Data selengkapnya dapat dilihat pada Tabel 1 .

Tabel1. Komposisi Zat Gizi Tepung Ikan Layang dan Ikan Selar

\begin{tabular}{lcc}
\hline \multicolumn{1}{c}{ Kandungan Zat Gizi } & Tepung Ikan \\
& Layang & Selar \\
\hline Air/\%bb & 11.65 & 7.34 \\
Abu/\% bk & 7.94 & 10.92 \\
Protein/\%bk & 89.26 & 89.86 \\
Lemak/\%bk & 0.34 & 0.53 \\
Zat Besi/ppm & 36.66 & 18.05 \\
Rendemen/\% & 15.96 & 12.65 \\
\hline
\end{tabular}

Kandungan zat gizi tepung ikan layang secara umum dapat memenuhi standar mutu FAO (1972) kecuali kadar air yaitu maksimal 10\% sedangkan hasil penelitian $11.65 \%$. Standar yang lain menurut FAO (1972) kadar protein min. 67.5\%, dan lemak maks. $0.75 \%$.

Pembuatan Biskuit dengan Penambahan Tepung Ikan Layang dan Difortifikasi Zat Besi

Pembuatan biskuit mengacu pada cara Setiawati (1984) (Gambar 1). Bahan baku utama pembuatan biskuit yaitu tepung terigu. Pemilihan tepung terigu Kunci Biru berdasarkan pada kandungan protein tepung terigu yang cocok untuk pembuatan makanan yang bersifat rapuh seperti biskuit, kue bolu dan cake (Setiawati 1994). Formula biskuit yang dibuat berdasarkan trial and error dapat dilihat pada Tabel 2 . Mikroenkapsulasi yang ditambahkan pada masing-masing formula pembuatan biskuit yaitu $2.3 \%$ dari berat bahan per formula.

\section{Daya Terima Biskuit dengan Berbagai Taraf Penambahan Tepung Ikan}

Panelis yang digunakan sebanyak 30 orang ibu hamil yang sedang memeriksakan kesehatannya di Puskesmas Bogor Tengah. Modus penerimaan panelis terhadap tujuh formula biskuit ikan yang dihasilkan baik warna, aroma, rasa, kerenyahan dan penerimaan umum berkisar antara 3 (biasa) dan 4 (suka) kecuali rasa formulai F1 yang memiliki modus 2 (tidak suka). Data modus hasil uji hedonik selengkapnya dapat dilihat pada Tabel 3. Sedangkan persentase penerimaan panelis terhadap warna biskuit berkisar $80 \%$ - 93.33\%, terhadap aroma $70 \%-86.67 \%$, rasa $60 \%$ - 90\%, kerenyahan $86.67 \%$ $100 \%$ dan penerimaan umum $83.33 \%-96.67 \%$. 
Telur, Gula halus dan Margarin *

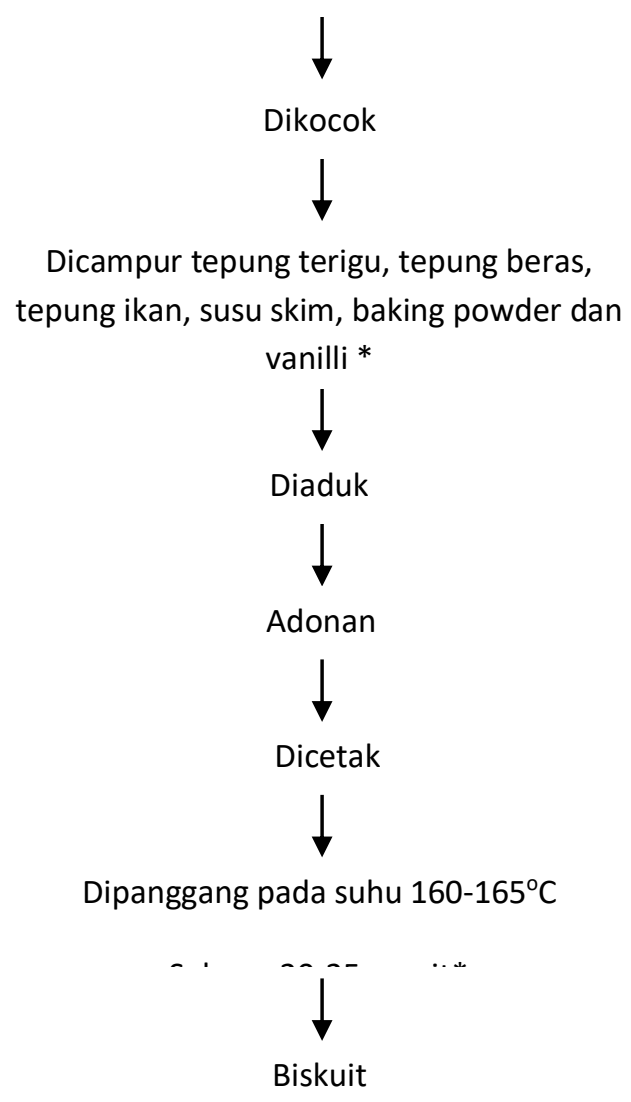

Gambar 1. Prosedur Pembuatan Biskuit dengan Penambahan Tepung Ikani (Modifikasi Setiawati 1984).

* Modifikasi yang Dilakukan

Tabel 2. Formula Adonan Pembuatan Biskuit dengan Penambahan Tepung Ikan Layang dan Difortifikasi Zat Besi (Berat Per Resep)

\begin{tabular}{lccccccc}
\hline \multicolumn{1}{c}{ Bahan } & \multicolumn{7}{c}{ Jenis Formula } \\
& Ktrl & 1 & 2 & 3 & 4 & 5 & 6 \\
\hline T. Terigu (g) & 40 & 40 & 40 & 40 & 40 & 40 & 40 \\
T. Beras (g) & 60 & 60 & 60 & 60 & 60 & 60 & 60 \\
T. Gula (g) & 85 & 85 & 85 & 85 & 85 & 85 & 85 \\
T. Ikan Layang (g) & $\mathbf{0}$ & $\mathbf{1 0}$ & $\mathbf{2 0}$ & $\mathbf{3 0}$ & $\mathbf{4 0}$ & $\mathbf{5 0}$ & $\mathbf{6 0}$ \\
Margarin (g) & 65 & 65 & 65 & 65 & 65 & 65 & 65 \\
Susu Skim (g) & 15 & 15 & 15 & 15 & 15 & 15 & 15 \\
Kuning Telur (g) & 22.5 & 22.5 & 22.5 & 22.5 & 22.5 & 22.5 & 22.5 \\
Baking Powder (g) & 2 & 2 & 2 & 2 & 2 & 2 & 2 \\
Vanili (g) & 1 & 1 & 1 & 1 & 1 & 1 & 1 \\
\hline Jumlah Adonan (g) & 290.5 & 300.5 & 310.5 & 320.5 & 330.5 & 340.5 & 350.5 \\
Jumlah Mikroenkapsulasi & 6.7 & 6.9 & 7.1 & 7.4 & 7.6 & 7.8 & 8.1 \\
Fe (g) & & & & & & & \\
\hline
\end{tabular}

Eddy Setyo M, Wiwin K,dan Nurillah A 
Hasil uji Friedman menunjukkan bahwa penambahan tepung ikan layang pada beberapa taraf yang berbeda tidak memberikan perbedaan yang nyata pada $\alpha=0.05$ baik penerimaan terhadap warna, aroma, kerenyahan dan penerimaan umum biskuit. Hal ini menunjukkan bahwa penambahan tepung ikan hingga $60 \mathrm{~g} / 350.5 \mathrm{~g}$ adonan $(17.11 \%$ tepung ikan) masih bisa diterima oleh panelis. Akan tetapi penambahan tepung ikan layang tersebut memberikan pengaruh yang sangat nyata $(\alpha=0.01)$ terhadap rasa biskuit. Berdasarkan hasil uji lanjut Multiple Comparison Test diketahui bahwa perbedaan rasa sangat nyata terlihat pada perlakuan F1 dengan F0 dan antara F1 dengan F3, akan tetapi perlakuan F0, F1 dan F3 tidak berbeda nyata dengan perlakuan lainnya. Hal ini diduga karena adanya beberapa panelis yang tidak terlalu suka terhadap ikan.

Atas dasar hasil uji kesukaan tersebut di atas (yaitu perlakuan yang tidak berbeda nyata dengan kontrol (F0) dan mempunyai kandungan tepung ikan tertinggi), maka biskuit dengan formula F6 adalah biskuit yang terpilih. Biskuit F6, selanjutnya diberi perlakuan tanpa rasa (kontrol), rasa jeruk nipis (R1) dan rasa coklat bubuk (R2). Biskuit dengan perlakuan penambahan rasa (untuk selanjutnya disebut biskuit rasa) ini kemudian diuji organoleptik.

Tabel 3. Modus Hasil Uji Hedonik Biskuit dengan Berbagai Taraf Penambahan Tepung Ikan

\begin{tabular}{lccccc}
\hline Jenis Perlakuan & Warna & Aroma & Rasa & Kerenyahan & Penerimaan Umum \\
\hline F0 (Kontrol) & 4 & 4 & $3 \& 4$ & 4 & 4 \\
F1 $(10 \mathrm{~g})^{*}$ & 4 & 3 & $2 \& 3$ & $3 \& 4$ & 3 \\
F2 $(20 \mathrm{~g})^{*}$ & 4 & 3 & 3 & 3 & 3 \\
F3(30 g)* & 4 & 4 & 4 & 4 & 4 \\
F4(40 g)* & 4 & 4 & $3 \& 4$ & 4 & 4 \\
F5(50 g)* & 4 & 3 & 3 & 4 & 3 \\
F6 (60 g)* & 4 & 3 & 4 & 4 & 3 \\
\hline
\end{tabular}

Keterangan : * Jumlah Penambahan Tepung Ikan per Resep

\section{Daya Terima Biskuit Rasa}

Modus penerimaan panelis terhadap biskuit rasa untuk warna, aroma, rasa, kerenyahan dan penerimaan umum berkisar 4 (suka), kecuali rasa untuk R1 (rasa jeruk nipis) yang bermodus sedang (3). Hal ini menunjukkan bahwa warna, aroma, rasa, kerenyahan dan penerimaan umum ketiga biskuit rasa tersebut dapat diterima oleh panelis. Hasil uji hedonik terhadap sifat organoleptik biskuit rasa dapat dilihat pada Tabel 4.

Tabel 4. Modus Hasil Uji Hedonik pada Berbagai Penambahan Rasa

\begin{tabular}{lccccc}
\hline \multicolumn{1}{c}{ Jenis Perlakuan } & W & A & R & K & PU \\
\hline F6 (tanpa rasa) & 4 & 4 & 4 & 4 & 4 \\
R1 (jeruk nipis) & 4 & 4 & 3 & 4 & 4 \\
R2 (coklat) & 4 & 4 & 4 & 4 & 4 \\
\hline $\begin{array}{c}\text { Keterangan : W = Warna } \\
\text { A = Aroma Kerenyahan }\end{array}$ R = Rasa & & & & \\
PU = Penerimaan Umum & & & &
\end{tabular}


Biskuit F6 mempunyai persentase penerimaan warna tertinggi (96.67\%), penerimaan tertinggi untuk aroma (80\%), penerimaan tertinggi untuk kerenyahan (100\%) dan penerimaan tertinggi untuk penerimaan umum (86.67\%). Sedangkan biskuit R1 (jeruk nipis) mempunyai penerimaan tertinggi untuk rasa yaitu $73.33 \%$ sedangkan biskuit R2 (coklat) mempunyai penerimaan tertinggi untuk aroma (80\%) dan penerimaan umum (86.67\%). Hasil uji Friedmen menunjukkan bahwa perlakuan penambahan rasa tidak menyebabkan perbedaan yang nyata $\alpha=0.05$ ) terhadap penerimaan warna, aroma, rasa, kerenyahan dan penerimaan umum biskuit rasa. Hal ini menunjukkan bahwa warna, aroma, rasa, kerenyahan dan penerimaan umum biskuit rasa tidak dipengaruhi penerimaannya oleh adanya penambahan rasa jeruk nipis maupun coklat bubuk. Berdasarkan kenyataan di atas maka untuk penelitian lanjutan dipilihlah biskuit rasa R2 (coklat) dengan beberapa kriteria coklat bubuk tersedia banyak di pasaran dan cenderung awet dibandingkan dengan jeruk nipis (ditambahkan dalam bentuk perasan segar) sehingga dari sudut kepraktisan coklat lebih mudah untuk dikembangkan.

\section{Penelitian Lanjutan}

Biskuit rasa coklat yang terpilih digunakan untuk penelitian lanjutan. Biskuit ini kemudian dikemas dalam plastik polipropilen untuk disimpan selama satu bulan dengan titik-titik pengamatan pada minggu ke 0 , minggu ke 2 dan minggu ke 4 .

\section{Daya Terima Biskuit Rasa Coklat Selama Penyimpanan}

Modus penerimaan panelis terhadap biskuit rasa R2 dan biskuit kontrol F0 selama penyimpanan baik terhadap warna, aroma, rasa, kerenyahan dan penerimaan umum berkisar 3 (biasa) dan 4 (suka). Hasil uji hedonik a dapat dilihat pada Tabel 5.

Tabel 5. Modus Hasil Uji Hedonik Biskuit Selama Penyimpanan

\begin{tabular}{lcccccc}
\hline \multicolumn{2}{c}{ Perlakuan } & \multicolumn{5}{c}{ Jenis Uji Hedonik } \\
\hline $\begin{array}{l}\text { Penambahan } \\
\text { Tepung Ikan }\end{array}$ & Lama Penyimpanan & W & A & R & K & PU \\
& & & & & & \\
\hline F0 (0 g) & 0 minggu (M0) & 4 & 4 & $3,4,4$ & 4 & 4 \\
& 2 minggu (M2) & 4 & 4 & 4 & 4 & 4 \\
R2 (60 g) & 4 minggu (M4) & 3 & 3 & & 4 & 4 \\
& 0 minggu (M0) & 4 & 4 & 4 & 4 & 4 \\
& 2 minggu (M2) & 4 & 4 & 4 & 4 & 4 \\
& 4 minggu (M4) & 4 & 3 & 4 & 4 & 3 \\
\hline
\end{tabular}

Keterangan : $\mathrm{W}=$ Warna; $\mathrm{K}=$ Kerenyahan $; \mathrm{A}=$ Aroma; $\mathrm{R}=$ Rasa

$\mathrm{PU}=$ Penerimaan Umum

Persentase penerimaan panelis terhadap warna kedua jenis biskuit selama penyimpanan terhadap warna berkisar $66.67 \%-93.33 \%$, terhadap aroma $73.33 \%-90 \%$, terhadap rasa $66.67 \%-90 \%$, dan terhadap kerenyahan $86.67 \%-100 \%$. Persentase 
penerimaan aroma dan rasa dari biskuit F0 selalu lebih tinggi daripada biskuit R2 selama penyimpanan. Hal ini diduga karena tepung ikan yang ditambahkan masih mempunyai bau amis yang tidak sepenuhnya hilang, walaupun lemaknya sudah diusahakan serendah mungkin melalui proses ekstraksi. Persentase penerimaan panelis terhadap uji hedonik selengkapnya dapat dilihat pada Tabel 6.

Hasil analisis sidik ragam menunjukkan bahwa perlakuan penambahan tepung ikan, perlakuan lama penyimpanan dan interaksi antara kedua perlakuan tersebut tidak memberikan perbedaan nyata $(\alpha=0.05)$ terhadap warna, aroma, rasa dan keremyahan. Hal ini berarti bahwa selama penyimpanan sebulan baik biskuit kontrol (F0) maupun biskuit rasa (R2) belum menunjukkan perubahan yang berarti baik terhadap warna, aroma, rasa dan kerenyahan. Selian itu juga biskuit merupakan produk kering sehingga mempunyai umur simpan yang relatif lama (Whiteley 1971).

Analisis Komposisi Kimia Biskuit

Analisis komposisi kimia biskuit dilakukan untuk mengetahui perubahan yang terjadi mulai pada adonan, biskuit hasil pemanggangan maupun selama penyimpanan.

Tabel 6. Persentase Penerimaan Panelis terhadap Biskuit Selama Penyimpanan

\begin{tabular}{|c|c|c|c|c|c|}
\hline \multicolumn{2}{|c|}{ Perlakuan } & \multicolumn{4}{|c|}{ Jenis Uji Hedonik } \\
\hline Penambahan & Lama & Warna & Aroma & Rasa & Kerenyahan \\
\hline Tepung Ikan & Penyimpanan & (\%) & (\%) & (\%) & (\%) \\
\hline \multirow[t]{3}{*}{$\mathrm{FO}(0 \mathrm{~g})$} & 0 mgg (M0) & 93.33 & 76.67 & 90.00 & 90.00 \\
\hline & 2 mgg (M2) & 66.67 & 86.67 & 90.00 & 86.67 \\
\hline & 4 mgg (M4) & 86.67 & 90.00 & 86.67 & 90.00 \\
\hline \multirow[t]{3}{*}{ R2 (60 g) } & 0 mgg (M0) & 76.67 & 76.67 & 66.67 & 90.00 \\
\hline & 2 mgg (M2) & 73.33 & 80 & 80.00 & 86.67 \\
\hline & 4 mgg (M4) & 76.67 & 73.33 & 76.67 & 100.00 \\
\hline
\end{tabular}

\section{Perubahan Kandungan Zat Gizi Selama Pengolahan}

Analisis komposisi kimia biskuit yang dilakukan pada adonan meliputi analisis proksimat (kadar air, abu, protein, dan lemak) dan analisis kandungan zat besi. Persantase kehilangan zat gizi akibat pemanggangan biskuit dapat dilihat pada Tabel. 7 . 
Tabel 7. Persentase kehilangan kandungan Zat Gizi Biskuit

\begin{tabular}{ccccc}
\hline Jenis Zat Gizi & Perlakuan & Adonan & Biskuit & $\begin{array}{c}\text { Kehilangan } \\
(\%)\end{array}$ \\
\hline Air & F0 & 10.76 & 2.98 & 72.30 \\
$(\%$ bb) & R2 & 14,08 & 2.33 & 83.45 \\
Abu (\%bk) & F0 & 1.63 & 1.62 & 0.61 \\
& R2 & 2.82 & 2.81 & 0.36 \\
Protein (\%bk) & F0 & 7.10 & 6.77 & 4,65 \\
& R2 & 20.28 & 20.01 & 1.33 \\
Lemak (\% bk) & F0 & 21.98 & 21.89 & 0.09 \\
& R2 & 18.78 & 18.67 & 0.59 \\
Zat Besi (ppm) & F0 & 932.75 & 928.46 & 0.46 \\
& R2 & 938.33 & 933.92 & 0.47 \\
\hline
\end{tabular}

Dari Tabel 7 dapat dilihat bahwa selama pemanggangan terjadi juga proses pengeringan yang cukup nyata dimana kadar air semula untuk F0 adalah $10.76 \%$ setelah dipanggang tinggal $2.98 \%$. Hal ini karena pada proses pemanggangan suhunya tinggi sehingga terjadi proses dehidrasi bahan akibat menguapnya air (Fellows 1988). Kehilangan yang cukup besar pada kandungan protein, karena protein akan mengalami denaturasi akibat adanya proses pemanasan sedangkan untuk kadar abu, lemak dan zat besi relatif tidak berubah.

\section{Perubahan Komposisi Zat Gizi Selama Penyimpanan}

Analisis komposisi zat gizi yang dilakukan terhadap biskuit F0 dan R2 selama penyimpanan meliputi analisis kadar air, abu, protein, lemak dan karbohidrat, analisis kandungan zat besi dan bilangan peroksida. Komposisi zat gizi biskuit selama penyimpanan dapat dilihat pada Tabel 8.

Air merupakan komponen penting dalam bahan makanan karena dapat mempengaruhi tekstur, penampakan dan citarasa makanan (Winarno 1997). Kadar air biskuit yang diuji berkisar $2.33 \% \mathrm{~s} / \mathrm{d} 3.93 \%$, semakin lama penyimpanan ada kecenderungan kadar air biskuit mengalami kenaikan. Hal ini karena kelembaban lingkungan yang relatif tinggi dan juga plastik yang digunakan untuk pengemasan masih bisa menyerap air sehingga biskuit yang disimpan masih bisa menyerap air dari lingkungannya.

Hasil analisis sidik ragam menunjukkan perlakuan penambahan tepung ikan dan perlakuan lama penyimpanan berpengaruh sangat nyata $(\alpha=0.01)$, akan tetapi interaksi antara kedua perlakuan tersebut tidak berpengaruh nyata $(\alpha=0.05)$ terhadap kadar air biskuit. Hasil uji lanjut Duncan $(\alpha=0.01)$ menunjukkan kadar air F0 berbeda nyata dengan kadar air R2. Sedangkan kadar air minggu ke-0 baik biskuit F0 maupun R2 berbeda nyata dengan kadar air minggu ke-2 dan minggu ke-4 akan tetapi kadar air minggu ke-2 dan minggu ke-4 tidak berbeda nyata. Hal ini diduga karena nilai kadar air dipengaruhi oleh suhu dan lama pemanggangan dalam oven, dan banyaknya air yang 
ditambahkan dalam adonan (Muchtadi 1989). Kadar air biskuit F0 dan R2 telah memenuhi standar yang telah ditetapkan oleh SNI No. 01-2973-92 yaitu dibawah 5\%.

Tabel 8. Rata-rata perubahan komposisi biskuit selama penyimpanan

\begin{tabular}{|c|c|c|c|c|c|c|c|c|}
\hline \multicolumn{2}{|c|}{ Perlakuan } & \multicolumn{6}{|c|}{ Komposisi Biskuit } & \multirow{2}{*}{$\begin{array}{c}\text { Bilangan } \\
\text { Peroksida } \\
(\mathrm{mg} \\
\mathrm{O} 2 / 100 \mathrm{~g})\end{array}$} \\
\hline $\begin{array}{l}\text { Penambahan } \\
\text { Tepung Ikan }\end{array}$ & $\begin{array}{c}\text { Lama } \\
\text { Penyimpanan }\end{array}$ & $\begin{array}{c}\text { Air } \\
(\% \% \text { bb })\end{array}$ & $\begin{array}{c}\text { Abu } \\
\text { (\%bk) }\end{array}$ & $\begin{array}{c}\text { Protein } \\
(\% \mathrm{bk})\end{array}$ & $\begin{array}{c}\text { Lemak } \\
(\% \mathrm{bk})\end{array}$ & $\begin{array}{c}\text { Karbohidrat } \\
(\% \text { bk })\end{array}$ & $\mathrm{Fe}(\mathrm{ppm})$ & \\
\hline F 0 & $0 \mathrm{mng}$ & 2.98 & 1.62 & 6.77 & 21.89 & 69.72 & 928.46 & 0.70 \\
\hline \multirow{2}{*}{$\begin{array}{l}\text { (biskuit } \\
\text { kontrol) }\end{array}$} & $2 \mathrm{mng}$ & 3.75 & 1.61 & 6.65 & 21.90 & 69.85 & 928.38 & 1.40 \\
\hline & $4 \mathrm{mng}$ & 3.93 & 1.61 & 6.60 & 21.78 & 70.01 & 928.28 & 3.14 \\
\hline \multirow{3}{*}{$\begin{array}{l}\text { R2 (tepung } \\
\text { ikan } 60 \mathrm{~g} \text { ) }\end{array}$} & $0 \mathrm{mng}$ & 2.33 & 2.81 & 20.01 & 18.67 & 58.51 & 933.92 & 0 \\
\hline & $2 \mathrm{mng}$ & 3.16 & 2.81 & 19.62 & 18.65 & 58.92 & 933.91 & 0 \\
\hline & $4 \mathrm{mng}$ & 3.32 & 2.82 & 19.56 & 18.61 & 59.01 & 933.29 & 0 \\
\hline
\end{tabular}

Abu merupakan sisa yang tertinggal setelah suatu bahan dibakar sampai bebas karbon. Kadar abu menggambarkan secara kasar kandungan mineral daris suatu bahan pangan (Winarno 1997). Kadar abu selama penyimpanan relatif tidak mengalami perubahan karena memang sifat abu yang sangat tahan tidak banyak terpengaruh oleh kondisi lingkungan (Desrosier 1979).

Hasil analisis sidik ragam menunjukkan bahwa perlakuan penambahan tepung ikan berpengaruh sangat nyata $(\alpha=0.01)$ akan tetapi perlakuan lama penyimpanan dan interaksi antara kedua perlakuan tersebut tidak berpengaruh nyata $(\alpha=0.05)$. Hal diduga tepung ikan secara relatif cukup banyak mengandung mineral dibandingkan dengan bahan baku pembuatan biskuit lainnya, sehingga penambahan tepung ikan akan menaikkan kadar abu biskuit.

Kadar abu biskuit baik jenis F0 maupun R2 melebihi standar yang ditetapkan SNI No. 01-2973-92 yaitu maksimum $1.50 \%$. Hal ini diduga selain berasal dari tepung ikan juga karena ke dalam biskuit ditambah zat besi sehingga semakin menambah mineral yang ada.

Protein merupakan zat gizi yang sangat penting karena peranannya yang sangat penting yaitu sebagai zat pembangun dan juga sekaligus sebagai sumber energi jika tubuh kekurangan intake karbohidrat. Kisaran kandungan protein biskuit $6.60 \%-20.01 \%$. Dari Tabel 8 nyata bahwa penambahan tepung ikan akan menaikkan kandungan protein biskuit karena kandungan protein tepung ikan lebih tinggi dibanding bahan penyusun biskuit lainnya.

Hasil analisis sidik ragam menunjukkan bahwa perlakuan penambahan tepung akan berpengaruh sangat nyata $(\alpha=0.01)$ akan tetapi perlakuan lama penyimpanan dan interaksi antara kedua perlakuan tidak berpengaruh nyata $(\alpha=0.05)$ terhadap kadar protein biskuit. Hal ini berarti kadar protein biskuit R2 lebih banyak kandungannya dibandingkan dengan 
biskuit F0. Penyebab tingginya kadar protein ini karena ada bahan dasar tepung ikan layang yang kandungan proteinnya sangat tinggi $(89.26 \% \mathrm{bk})$. Sedangkan tidak berbeda nyatanya kadar protein selama penyimpanan karena pengemas yang digunakan mampu melindungi protein dari kerusakan baik karena cahaya, oksidasi maupun kerusakan yang lainnya.

Kadar protein biskuit F0 lebih rendah dari standar SNI No. 01-2973-92 yaitu minimal 9\% sedangkan biskuit R2 sudah memenuhi syarat SNI. Jika dibandingkan dengan kecukupan protein untuk ibu hamil sebesar $60 \mathrm{~g} /$ orang/per hari (Muhilal et al. 1998) maka untuk memenuhi kecukupan tersebut seorang ibu harus mengkonsumsi 304.11 g biskuit per hari atau $51-52$ keping. Hal ini karena rata-rata kandungan protein biskuit $19.73 \%$.

Lemak merupakan bagain yang penting dalam pembuatan biskuit. Lemak berperan menambah kalori serta memperbaiki tekstur dan citarasa makanan (Winarno 1997). Kadar lemak biskuit F0 dan R2 berkisar antara $18.61-21.90 \%$.

Hasil analisis sidik ragam menunjukkan bahwa perlakuan penambahan tepung ikan layang berpengaruh sangat nyata $(\alpha=0.01)$ akan tetapi perlakuan lama penyimpanan dan interaksi antara kedua perlakuan tersebut tidak berpengaruh nyata $(\alpha=0.05)$ terhadap kadar lemak biskuit. Hal ini berarti bahwa kadar lemak biskuit F0 berbeda dengan kadar lemak biskuit R2. Sedangkan perlakuan penyimpanan dan interaksinya yang tidak berbeda nyata karena perubahan lemak selama penyimpanan sangat kecil bahkan cenderung tetap. Hal ini diduga pengemas yang digunakan mampu melindungi dan mencegah kerusakan lemak selama penyimpanan. Adapun kadar lemak dari biskuit F0 dan R2 telah memenuhi standar yang ditetapkan berdasarkan SNI No. 01-2973-92 yaitu minimal $9.50 \%$.

Karbohidrat mempunyai peranan penting dalam menentukan karakteristik bahan makanan seperti warna, rasa, dan tekstur (Winarno 1997). Kadar karbohidrat biskuit F0 dan R2 berkisar $58.51 \%-70.01 \%$.

Analisis yang dilakukan menunjukkan bahwa perlakuan penambahan tepung ikan berpengaruh sangat nyata $(\alpha=0.01)$ akan tetapi perlakuan lama penyimpanan dan interaksi antara kedua perlakuan tersebut tidak berpengaruh nyata $(\alpha=0.05)$. Hal ini artinya kandungan karbohidrat biskuit F0 berbeda dengan kandungan biskuit R2. Sedangkan perlakuan lama penyimpanan dan interaksi antara kedua perlakuan tidak berbeda karena selama penyimpanan memang tidak terjadi perubahan baik karena kerusakan atau reaksireaksi lainnya atau dengan kata lain komposisi karbohidrat selama penyimpanan tidak berubah. Hal ini karena karbohidrat relatif stabil selama penyimpanan. Adapun kandungan karbohidrat biskuit baik F0 maupun R2 kurang dari yang ditentukan oleh SNI No. 01-2973-92 yaitu minimal 70\%. Hal ini tidak menjadi masalah karena memang biskuit ini khusus ditujukan untuk ibu hamil, sehingga yang dipentingkan kandungan proteinnya, jika karbohidratnya kurang dapat dipenuhi oleh makanan yang lain.

Zat besi merupakan salah satu unsur mineral yang sangat dibutuhkan oleh tubuh dan bersifat mikro element atau trace element (hanya terdapat dalam jumlah yang kecil di dalam tubuh) sehingga zat besi harus dicukupi dari makanan yang dikonsumsi (Winarno 1997). Kadar zat besi yeng terdapat pada biskuit F0 maupun R2 berkisar 928.28 ppm $933.92 \mathrm{ppm}$. 
Analisis sidik ragam tehadap kandungan zat besi menunjukkan bahwa perlakuan penambahan tepung ikan, perlakuan lama penyimpanan dan interaksi antara kedua perlakuan tersebut tidak berpengaruh nyata $(\alpha=0.05)$. Hal ini diduga karena penambahan tepung ikan yang ditambahkan tidak banyak mengandung zat besi sehingga formula F0 dan R2 tidak berbeda kandungan zat besinya. Sedangkan interaksi yang tidak berbeda nyata menunjukkan bahwa zat besi tidak berubah atau tidak rusak selama penyimpanan karena memang zat besi relatif stabil dalam suhu ruang.

Angka kecukupan zat besi untuk ibu hamil per kapita per hari adalah $46 \mathrm{mg}$ (Muhilal et al. 1998), sedangkan rata-rata kandungan zat besi pada biskuit tepung ikan adalah $933.71 \mathrm{ppm}$ atau $93.371 \mathrm{mg} / 100 \mathrm{~g}$. Dengan demikian untuk memenuhi kecukupan zat besi ibu hamil diperlukan biskuit ikan sebanyak $49.27 \mathrm{~g}$ atau sekita $8-9$ keping biscuit ikan/orang/hari.

Bilangan peroksida digunakan untuk mengukur derajat kerusakan yang disebabkan oleh adanya ketengikan minyak/lemak (Ketaren 1986). Proses ketengikan sangat dipengaruhi oleh adanya prooksidan dan antioksidan. Prooksidan akan mempercepat terjadinya oksidasi sedangkan antioksidan akan menghambatnya (Winarno 1997). Bilangan peroksida yang terukur selama penyimpanan biskuit ikan berkisar 0 $3.14 \mathrm{mg}$ oksigen $/ 100 \mathrm{~g}$.

Analisis sidik ragam terhadap bilangan peroksida yang terukur menunjukkan bahwa perlakuan penambahan tepung ikan, perlakuan lama penyimpanan dan interaksi antara kedua perlakuan berpengaruh sangat nyata $(\alpha=0.01)$. Hal ini menunjukkan bahwa penambahan tepung ikan pada biskuit R2 berpengaruh pada kandungan peroksida selama penyimpanan. Uji lanjut Duncan $(\alpha=0.01)$ menunjukkan bahwa penyimpanan biskuit pada minggu ke- 4 berbeda nyata dengan kandungan peroksida biskuit pada minggu ke- 0 dan minggu ke-2, akan tetapi bilangan peroksida tidak berbeda nyata antara minggu ke-0 dan minggu ke-2. Sedangkan interaksinya menunjukkan bahwa perlakuan F0 dengan lama penyimpanan 4 minggu berbeda nyata dengan penyimpanan lainnya baik minggu ke-0 maupun minggu ke-2. Hal ini menunjukkan bahwa mulai minggu ke-2, biskuit yang disimpan sudah mulai terbentuk peroksida, bahkan pada minggu ke-4 kandungan peroksida cukup tinggi yaitu $3.14 \mathrm{mg}$ oksigen/100 g biskuit. Oleh karena itu walaupun secara fisik belum menunjukkan penyimpangan bau (belum terbentuk bau tengik) pada biskuit yang disimpan selama 4 minggu tetapi tetap harus lebih berhati-hati dalam mengkonsumsinya. Ketengikan sebetulnya dapat dihambat dengan banyak menambahkan gula, karena gula dapat mengurangi proses oksidasi (Winarno 1997).

\section{SIMPULAN}

Berdasarkan pertimbangan kadar abu, kadar lemak, zat besi, rendemen, harga dan produksinya per tahun maka tepung ikan yang terpilih adalah tepung ikan layang. Penambahan tepung ikan layang dapat dilakukan sampai taraf $60 \mathrm{~g}$ per $350.5 \mathrm{~g}$ adonan

Penambahan tepung ikan layang pada berbagai taraf dan penambahan zat besi tidak memberikan perbedaan yang nyata terhadap penerimaan warna, aroma dan kerenyahan tetapi berbeda nyata penerimaan terhadap rasa. Penambahan rasa air perasan jeruk (R1) dan coklat bubuk (R2) dan juga kontrol tidak memberikan perbedaan yang nyata terhadap warna, aroma, rasa dan kerenyahan. 
Perlakuan penambahan tepung ikan, perlakuan lama penyimpanan dan interaksi antara kedua perlakuan tidak berbeda nyata penerimaannya terhadap warna, aroma, rasa dan kerenyahan.

Kandungan zat gizi biskuit F0 dan R2 memiliki kecenderungan menurun selama pengolahan dan tetap selama penyimpanan. Biskuit yang dihasilkan sudah memenuhi standar SNI Mo. 01-2973-92 kecuali kadar karbohidratnya. Penambahan tepung ikan berpengaruh nyata terhadap kadar air, abu, protein, lemak karbohidrat dan bilangan peroksida. Lama penyimpanan juga berpengaruh terhadap kadar air dan bilangan peroksida tetapi tidak berpengaruh nyata terhadap kadar abu, protein, lemak, karbohidrat dan zat besi. Sedangkan interaksi antara keduanya hanya berpengaruh pada bilangan peroksida.

\section{DAFTAR PUSTAKA}

Damayanthi E, S A Marliyati, H Syarif, D Sukandar. 1997. Percobaan Makanan. Diktat Jurusan GMSK, Fakultas Pertanian IPB Bogor.

Direktorat Jenderal Perikanan Tangkap. 2014. Statistik Perikanan Tangkap Indonesia 2013. Kementerian Kelautan dan Perikanan. Jakarta.

Dwiriani. 1997. Zat Besi dan Produktifitas Kerja. Buletin Sadar Pangan dan Gizi. 6(2). 2-3.

Dwiyitno. 1995. Pengaruh Metode Pengolahan dan Jenis Ikan terhadap Kualitas Tepung Ikan untuk Pangan. Skripsi yang Tidak Dipublikasikan Jurusan Pengolahan Hasil Perikanan, Fakultas Perikanan IPB Bogor.

Komari. 1995. Enkapsulasi Yodium dan Zat Besi untuk Fortifikasi Ganda pada Makanan untuk Menanggulangi GAKY dan AGB. Laporan Penelitian Pusat Penelitian dan Pengembangan Gizi, Bogor.

Moeljanto. 1982. Pengolahan Hasil-hasil Samping Ikan. Penebar Swadaya. Jakarta.

Muhilal, F. Jalal \& Hardinsyah.1998. Angka Kecukupan Gizi yang Dianjurkan. Dalam F G Winarno (Ed.), Widyakarya Pangan dan Gizi VI (hlm 843-879). Lembaga Ilmu Pengetahuan Indonesia. Jakarta.

Setiawati. 1984. Pembuatan Biskuit dari Konsentrat Dedak Padi. Skripsi yang Tidak Dipublikasikan Jurusan. Teknologi Pangan dan Gizi, Fakultas Teknologi Pertanian IPB Bogor.

Soekirman. 2000. Ilmu Gizi dan Aplikasinya untuk Keluarga dan Masyarakat. Direktorat Jemderal Pendidikan Tinggi Departemen Pendidikan Nasional. Jakarta.

Walpoel RE. 1995. Pengantar Statistik. Edisi ke-3. Alih bahasa : Bambang Sumantri. PT Gramedia. Jakarta.

Whiteley P.R. 1971. Biscuit Manufacture : Fundamental of In-live Production. Applied Science Publishers. London.

Winarno F G. 1997. Kimia Pangan dan Gizi. Gramedia Pustaka Utama. Jakarta.

Winarno \& S L B Jenie. 1984. Kerusakan Bahan Pangan. Gramedia. Jakarta. 